\title{
Mule deer-induced mortality of mountain big sagebrush
}

\author{
E. DURANT MCARTHUR, A. CLYDE BLAUER, AND STEWART C. SANDERSON
}

\begin{abstract}
A fence line contrast was provided by a deer fence that bisected a mountain bis sagebrush (Artemisia tridentata ssp. vaseyana) community. The sagebrush community was located on an exposed, west-facing slope that was generally swept free of snow during the severe winters of 1982-83 and 1983-84. On the freeway side of the fence, the site was esaentially free of browsing animals, while above the fence, the shrubs were exposed to concentrations of mule deer (Odocoileus hemionus). Considerable big sagebrush mortality was evident after the 2 successive winters of heavy snowfall. Big sagebrush mortality and partial dieback of portions of the canopy were significantly $(P<0.05)$ higher in the portion of the community exposed to browsing. Herbaceous species composition also differed between the protected and browsed areas with a higher portion of annual species found in the browsed community. A large number of big sagebrush seedlings germinated in 1984, but falled to establish by 1986 . Excessive use of native plants by native large herbivores can have lasting efiects on plant communities.
\end{abstract}

Key Words: Artemisia tridentata ssp. vaseyana, annuals, cheatgrass, Bromus tectorum, browsing, succession, Odocolleus hemionus

Big sagebrush (Artemisia tridentata), mountain big sagebrush (A.t. ssp. vaseyana) in particular, is important winter forage for wildlife and livestock (Welch and McArthur 1986, Personius et al. 1987, Welch et al. 1987). Defoliation (Allred 1941, Hsiao 1986), artificial clipping (Cook and Child 1971), and heavy browsing

\footnotetext{
Authors are supervisory research geneticist, USDA Forest Service, Intermountain Research Station, Shrub Sciences Laboratory, Provo, Utah 84601; professor, Division of Natural Sciences, Snow College, Ephraim, Utah 84627; and research associate, USDA Forest Service, Intermountain Research Station. Shrub Sciences Laboratory, Provo, Utah 84601 . At the time of the research, Blauer was botanist, USDA Forest Service, Intermountain Research Station, Great Basin Experimental Range, Ephraim, Utah 84627.

Research was facilitated by the cooperative efforts of Pittmann-Robertson Project W82R personnel (cooperators: Utah Division of Wildlife Resources and Intermountain Research Station). The authors thank Bradford Petch and Gary L. Jorgensen for assistance. Jack D. Brotherson, Stephen B. Monsen, David A. Pyke, Richard Stevens, and Fred J. Wagstaff provided useful input to various phases of the study

Manuscript accepted I October 1987.
}

(Smith 1949) have all been shown to cause loss of vigor and mortality in sagebrush taxa of the subgenus Tridentatae. Several researchers have suggested heavy fall, winter, and early spring grazing as a means to reduce sagebrush and favor perennial grass for livestock grazing (Frischknecht and Harris 1973, Laycock 1979). Destruction of sagebrush and other perennials leads to vegetative type conversion in the direction of nonproductive exotic annuals (Pickford 1932, Cottam and Evans 1945, Young et al. 1979, Brotherson and Brotherson 1981, Mack 1981). In the summer of 1984, we observed sizable areas of apparent sagebrush mortality on west-facing, exposed slopes after 2 winters of heavy snow accumulation. The area we sampled is divided by a deerproof highway right-of-way fence that provided a dramatic visual contrast of sagebrush vigor. The deer-proof fence was constructed in 1972 (personal communication, Utah Department of Transportation). This investigation documents the early successional dynamics of the plant community near Santaquin, Utah.

\section{Materials and Methods}

\section{Study Site}

The study site (Fig. 1) is adjacent to the I-15 freeway just south of the Utah-Juab County line (R.1 East, T.10 South, S.22 extending into S.23). The natural plant community is a mountain big sagebrush-bluebunch wheatgrass (Agropyron spicatum) - Sandberg bluegrass (Poa secunda) habitat type that has been degraded so that it includes a large quantity of annuals and biennials (Table 1). The sagebrush was determined to be mountain big sagebrush on morphological (McArthur 1983) and ultraviolet water soluble coumarin compound florescence characteristics (McArthur et al. 1981). Elevation ranges from 1,570 to $1,600 \mathrm{~m}$ along the right-ofway fence where the study transects were located to $1,680 \mathrm{~m}$ at the crest of the eastern ridge. The area is an undulating but west-facing slope with a general slope of 20 to $30 \%$. The impacted area to the east of the right-of-way fence is 21 ha. The comparable area within the highway right-of-way is 1 ha. Domestic livestock have not used the area for several years. 


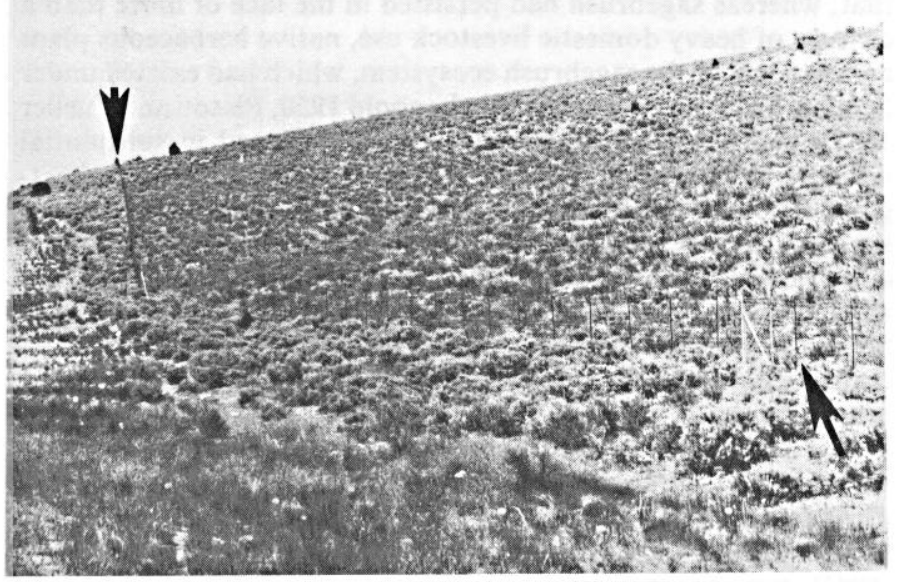

Fig. 1. Photograph of study site along I-15, south of Santaquin, Utah. Note vigorous mountain big sagebrush below fence (arrows) but less vigorous and dead sagebrush above it.

Table 1. Species list from study site. ${ }^{1}$

\begin{tabular}{|c|c|c|c|c|}
\hline \multirow[b]{2}{*}{ Species } & \multirow[b]{2}{*}{ Origin $^{2}$} & \multirow[b]{2}{*}{$\begin{array}{l}\text { Longe- } \\
\text { vity }^{3}\end{array}$} & \multicolumn{2}{|c|}{ Frequency } \\
\hline & & & $\begin{array}{c}\text { Browsed } \\
-\%-\end{array}$ & nbrowsed \\
\hline \multicolumn{5}{|l|}{ Grasses } \\
\hline Agropyron cristatum & A & $\mathbf{P}$ & 0 & 5.0 \\
\hline Agropyron spicatum & I & $\mathbf{P}$ & 10.0 & 32.5 \\
\hline Bromus tectorum & A & A & 100.0 & 100.0 \\
\hline Bromus commutatus & A & $\mathbf{P}$ & 37.5 & 2.5 \\
\hline Poa bulbosa & A & $\mathbf{P}$ & 0 & $0^{4}$ \\
\hline Poa secunda & I & $\mathbf{P}$ & 30.0 & 22.5 \\
\hline \multicolumn{5}{|l|}{ Forbs } \\
\hline Allyssum alyssoides & A & A & 97.5 & 85.0 \\
\hline Arabis pulchra & I & $\mathrm{P}$ & 2.5 & 20.0 \\
\hline Arenaria sp. & I & $\mathbf{P}$ & 0 & 12.5 \\
\hline Artemisia ludoviciana & I & $\mathbf{P}$ & 0 & $0^{4}$ \\
\hline Astragalus utahensis & I & $\mathbf{P}$ & 0 & 5.0 \\
\hline Cardaria draba & A & $\mathbf{P}$ & 0 & 2.5 \\
\hline Epilobium paniculatum & I & A & 87.5 & 50.0 \\
\hline Erigeron divergens & I & B & 72.5 & 57.5 \\
\hline Erigeron $\mathrm{sp}$. & I & A & 17.5 & 0 \\
\hline Eriogonum sp. & I & A & 2.5 & 12.5 \\
\hline Erodium cicutarium & A & A & 2.5 & 0 \\
\hline Helianthus annuus & I & A & 62.5 & 32.5 \\
\hline Lactuca serriola & A & B & 92.5 & 30.0 \\
\hline Leucelene ericioides & I & $\mathbf{P}$ & 2.5 & 0 \\
\hline Melilotus alba & A & B & 5.0 & 2.5 \\
\hline Melilotus officinalis & A & B & $0^{4}$ & 0 \\
\hline Polygonum douglasii & I & $\mathbf{A}$ & 2.5 & 0 \\
\hline Ranuclus testiculatus & A & A & 37.5 & 2.5 \\
\hline Streptanthus cordatus & I & $\mathbf{P}$ & 0 & $0^{4}$ \\
\hline Tragopogon dubius & A & B & 37.5 & 15.0 \\
\hline \multicolumn{5}{|l|}{ Woody Plants } \\
\hline \multicolumn{5}{|l|}{ Artemisia tridentata } \\
\hline ssp. vaseyana & I & $\mathbf{P}$ & $75.0^{5}$ & 80.0 \\
\hline Cowania stansburiana & I & $\mathrm{P}$ & 2.5 & $0^{4}$ \\
\hline Gutierrezia sarothrae & I & $\mathrm{P}$ & $0^{4}$ & 0 \\
\hline Juniperus osteosperma & I & $\mathbf{P}$ & 0 & $0^{4}$ \\
\hline
\end{tabular}

${ }^{1}$ After Welsh et al. 1981, 1987 except Artemisia tridentata ssp. vaseyana and Cowania stansburiana for which see McArthur et al. 1981, 1983.

${ }^{2} \mathrm{~A}=$ adventive, $\mathrm{I}=$ indigenous.

${ }^{3} \mathrm{~A}=$ annual, $\mathrm{B}=$ biennial (some may be annual, too), $\mathrm{P}=$ perennial.

${ }^{4}$ Present on transect but not in quadrats.

${ }^{5}$ Does not include standing dead.

\section{Methods}

Four paired, 50-m transects were located randomly along the $600 \mathrm{~m}$ length of the right-of-way fence in and opposite the impacted area. None of the transects overlapped linearly. None of the transects appeared to have been physically disturbed by the highway or fence construction. Frequency and density of each species (number of individual plants, including seedlings) was collected on $\mathrm{m}^{2}$ quadrats every $5 \mathrm{~m}$ along transects ( 10 per transect). Data from individual mountain big sagebrush plants were collected from the mature plant nearest each 5-m transect mark. Height, total crown diameter, and live crown diameter were recorded in centimeters, and vigor and use were recorded on a numerical rating scale. Vigor scale was $0=$ dead to $4=$ vigorous. The use scale was $1=$ no use observed to 4 = very heavy use with most leaves gone, annual twig growth consumed. Deer pellet group data were collected along each transect in a $2-\mathrm{m}$ wide band $(2$ by $50 \mathrm{~m}$ ). Data were collected during the first week of August 1984. The number of sagebrush seedlings per quadrat was collected again on 10 July 1986 . Seedlings were defined as any young plant less than $10 \mathrm{~cm}$ tall.

Data were analyzed using t-tests, Mann-Whitney U tests, $\chi^{2}$ analysis, and one-way analysis of variance (Pollard 1977). Percentage data were arcsine transformed before analysis but changed back to percentage for presentation.

\section{Results and Discussion}

\section{Sagebrush Plants}

There was a significant $(P<0.5)$ mortality and decline in vigor of mountain big sagebrush plants in the area behind the right-of-way fence where mule deer (Odocoileus hemionus) had access (Table 2).

Table 2. Some comparisons of plant densities between browsed and nonbrowsed transects, $1984 .^{1}$

\begin{tabular}{|c|c|c|c|c|}
\hline Plant group & Browsed & $\begin{array}{c}\text { Non- } \\
\text { browsed }\end{array}$ & $\mathrm{t}$ or $\mathrm{U}^{2}$ & $\mathbf{P}^{3}$ \\
\hline Annual grasses & 96.2 & 66.6 & 1.42 & .17 \\
\hline Annual forbs & 73.3 & 42.2 & 2.90 & $.03 *$ \\
\hline Total annuals & 169.5 & 108.8 & 4.52 & $.01^{*}$ \\
\hline Perennial grasses & 0.7 & 1.4 & 1.23 & .15 \\
\hline Perennial forbs & 0.3 & 1.0 & 1.36 & .14 \\
\hline Total perennials ${ }^{4}$ & 1.0 & 2.4 & 1.67 & .10 \\
\hline Sagebrush plants ${ }^{5}$ & 1.8 & 1.9 & 0.85 & .45 \\
\hline Live sagebrush plants 5 & 1.2 & 1.8 & 3.51 & $.02 *$ \\
\hline Sagebrush vigor ${ }^{6}$ & 1.4 & 2.6 & 16 & $.05^{*}$ \\
\hline Sagebrush use ${ }^{6}$ & 3.3 & 1.2 & 16 & $.05^{*}$ \\
\hline Deer pellet groups & 0.5 & 0.01 & 5.34 & $.01 * *$ \\
\hline
\end{tabular}

'Data, except scaled ratings ${ }^{6}$, presented on a number per square meter basis; $n=$ in all cases.

${ }^{2}$ Paired t-tests except for scaled ratings for which a Mann-Whitney U test was used (see Methods section).

3* $=P \leq 0.05, * *=P \leq 0.01$

${ }^{4}$ Excludes woody plants.

sSagebrush plants category includes standing dead plants. The live sagebrush plants browsed on transects were reduced in vigor as well.

${ }^{6}$ These data were based on rating scales: Vigor: $0=$ dead...4 4 vigorous. Use: $1=$ no use...4 = heavy use (see Methods section).

Mule deer forage access was limited to the exposed slopes with less snow accumulation in the area during much of the 1982-1983 and 1983-1984 winters. These winters had heavy snow accumulation. From 1 November to $31 \mathrm{March}$ for those winters, 317 and $326 \mathrm{~mm}$ of precipitation, most of it snow, fell at the Santaquin weather station, which is located about $3 \mathrm{~km}$ away at a comparable elevation $(1,561 \mathrm{~m})$ (NOAA 1982, 1983, 1984). That is 141 and $148 \%$ of normal precipitation $(225 \mathrm{~mm}$ ) for ther period (Stevens et al. 1983). The heavy concentration of mule deer is demonstrated by the highly significant differences of pellet groups and of sagebrush use on the browsed transect data as opposed to the nonbrowsed transects (Table 2). Mountain big sagebrush plants were quite similar 
in height and crown diameter on both sides of the right-of-way fence $(\bar{x}=56.7 \mathrm{~cm}$ tall on browsed side versus 69.4 on the nonbrowsed side; $\bar{x}=84.9 \mathrm{~cm}$ crown diameter on the browsed side versus 93.2 on the nonbrowsed side), but the number of dead plants was significantly different $(P<0.05)$ between the 2 sides of the fence (Table 2). Live crown diameter was also different (by analysis of variance: $\mathrm{DF}=1, \mathrm{~F}=30.6, P<0.01$ ): plants in the browsed transects had an average crown dieback of $64 \%$ in comparison to a $17 \%$ dieback in the nonbrowsed transects. Dead plants were 11 times as common on the browsed side of the fence. However, in areas of low relief on the browsed side of the fence, where mountain big sagebrush plants were afforded protection by deep snow cover, sagebrush plants were healthy.

Our results support published reports that sagebrush does not tolerate heavy defoliation. Cook and Child (1971) demonstrated that simulated browsing (clipping) twice (winter and spring) killed all big sagebrush plants and all but about $3 \%$ of black sagebrush plants (Artemisia nova). Single clipping events were also damaging to big and black sagebrush plants; late spring was almost as damaging as the double event, but winter and early spring were less damaging (Cook and Child 1971). Smith (1949) reported that twice as many big sagebrush plants were dead as alive on a heavily used mule deer winter range, whereas on an adjacent livestock range 6 times as many big sagebrush plants were alive as were dead. Smith did not recognize big sagebrush at the subspecies level, but his study area currently supports mountain big sa gebrush. Defoliation of various sagebrush taxa by insects also causes loss of plant vigor and death (Allred 1941, Hsiao 1986, McArthur unpublished). There are other reports in the literature describing mortality of sagebrush induced by browsing, but they are mostly anecdotal. This report, so far as we know, is the first to quantify the effects of heavy mule deer browsing on mountain big sagebrush. Such information is important inasmuch as some populations of mountain big sagebrush are preferred mule deer winter forage (Welch and McArthur 1986, Personius et al. 1987), and sagebrush in general is an important winter food for mule deer and other animals throughout the West (McArthur and Welch 1986).

\section{Vegetative Community Dynamics}

The natural plant community of the study site was degraded even prior to heavy browsing brought on by the concentration of mule deer during the winters of 1982-1983 and 1983-1984. This condition is evident by the number of annual grasses and annual and biennial forbs present on the nonbrowsed (highway right-ofway) transects (Table 2). Seeding along the freeway right-of-way on the roadcut did introduce a few plants that subsequently invaded the nonbrowsed transects, crested wheatgrass (Agropyron cristatum) and perhaps sweetclover (Melilotus spp.) (Table 1). However, prior to construction of the freeway and fence in 1972, the plant community was unified and in all likelihood homogeneous. Some differences may have been emerging by 1982 due to different animal use patterns as a consequence of the construction of the deer-proof fence. We believe, however, that the high snowfall of back-to-back winters (1982-1984) forced deer into an area relatively free of snow because of its sloping western exposure and hence with available forage but bounded by areas of deeper snow and the deer-proof fence. Deer use was unequivocally heavy in the browsed transects. Both sagebrush use and density of deer pellet groups were significantly higher there than on the unbrowsed transects (Table 2). The value of 0.52 pellet groups per $\mathrm{m}^{2}$ (= $5,200 / \mathrm{ha}$ or $2,105 / \mathrm{ac}$ ) is high. Using a value of 14 pellet groups per day per deer (Smith 1964), our data indicate approximately 370 deer days use per hectare (150 per acre). We do not imply precision with these data because of our relatively small sampling area and the possibility that some of the pellets were not of the current season. Nevertheless, the data indicate heavy deer use.

Young et al. (1979) reviewed the status of the greater sagebrush ecosystem and made a case for an extensive disclimax situation. Brotherson and Brotherson (1981) documented degradation of sagebrush communities in Utah Valley in the general area of our study. Ellison (1960) reviewed rangeland grazing systems and concluded that some plant communities are susceptible to animalinduced and long-lasting change. Young et al. (1979) contended that, whereas sagebrush had persisted in the face of more than a century of heavy domestic livestock use, native herbaceous plant components of the sagebrush ecosystem, which had existed under light herbivore use for millennia (Leopold 1950, Platou and Tueller 1985), had not fared well but had been replaced in substantial measure by short-lived exotics. At our study site these are cheatgrass (Bromus tectorum), alyssum (Alyssum alyssoides), prickly lettuce (Lactuca serriola), yellow salsify (Tragopogon dubius) and a few others (Table 1). The recent heavy browsing pressure documented in this study, however, has dramatically shifted the balance further toward the disclimax. Note the overall (Table 2) and particular species (Table 1) increases for the short-lived plants in the browsed area.

Our data represent only one point in time. However, it is easy to visualize that sustained perturbations, whether by browsing animals as demonstrated in this case or by grazing animals as suggested by Pickford (1932), Ellison (1960), and Brotherson and Brotherson (1981), can change vegetative communities for long periods. Fire, another perturbation, can also have dramatic effects. Cheatgrass is a fire and other disturbance climax species that sustains itself by burning and reburning or other disturbance factors, thus eliminating much of the native perennial competition (Piemsiel 1951, Mack 1981).

We wondered if mountain big sagebrush was recovering after 2 open winters (NOAA 1984, 1985, 1986). None of the dead sagebrush had resprouted by 1986 . Furthermore, the promising cohort of seedlings on the browsed side of the fence $\left(39.0 / \mathrm{m}^{2}\right)$ of 1984 was reduced to a very low level in $1986\left(0.05 / \mathrm{m}^{2}\right)\left(\chi^{2}=176, \mathrm{DF}=1\right.$, $P<0.01)$. We suspect the cohort was lost because of competition with the dense stand of annuals and normally very hot and dry mid-summer conditions. August 1985 was even drier than normal ( $<5 \mathrm{~mm}$ vs $28 \mathrm{~mm}$ of precipitation) (NOAA 1985). No seedlings were found in any quadrat in 1984 or 1986 on the highway right-ofway side of the fence.

\section{Literature Cited}

Allred, B.W. 1941. Grasshoppers and their effect on sagebrush on the Little Powder River in Wyoming and Montana. Ecology 22:377-392.

Brotherson, J.D., and W.T. Brotherson. 1981. Grazing impacts on the sagebrush communities of central Utah. Great Basin Natur. 41:335-340.

Cook, C.W., and R.D. Child. 1971. Recovery of desert plants in various states of vigor. J. Range Manage. 24:339-343.

Cottam, W.P., and F.R. Evans. 1945. A comparative study of the vegetation of grazed and ungrazed canyons of the Wasatch Range, Utah. Ecology 26:171-181.

Ellison, L. 1960. Influence of grazing on plant succession of rangelands. Bot. Rev. 26:1-78.

Frischknecht, N.C., and L.E. Harris. 1973. Sheep can control sagebrush on seeded range if... Utah Sci. 34:27-30.

Hsino, T.J. 1986. Biology and demography of the sagebrush defoliator and its impacts on big sagebrush. p. 191-198. In: E.D. McArthur and B.L. Welch (compilers). Proceedings-Symposium on the biology of Artemisia and Chrysothamnus. USDA Forest Service Gen. Tech. Rep. INT200. Intermountain Research Station, Ogden, Utah.

Laycock, W.A. 1979. Management of sagebrush. Rangelands 1:207-210.

Leopold, A.S. 1950. Deer in relation to plant succession. J. Forestry 48:675-678.

Mack, R.N. 1981. The invasion of Bromus tectorum L. into western North America: an ecological chronicle. Agro-Ecosystems 7:145-165.

McArthur, E.D. 1983. Taxonomy, origin, and distribution of big sagebrush (Artemisia tridentata) and allies (subgenus Tridentatae). p. 3-13. In: K.L. Johnson (ed.). Proceedings of the First Utah Shrub Ecology Workshop. College of Natural Resources, Utah State Univ., Logan.

McArthur, E.D., C.L. Pope, and D.C. Freemen. 1981. Chromosomal studies of subgenus Tridentatae of Artemisia: evidence for autopolyploidy. Amer. J. Bot. 68:589-605. 
McArthur, E.D., H.C. Stutz, and S.C. Sandernon. 1983. Taxonomy, distribution, and cytogenetics of Purshia, Cowania, and Fallugia (Rosoidae, Rosaceae). p. 4-24. In: A.R. Tiedemann and K.L. Johnson (compilers). Proceedings-research and management of bitterbrush and cliffrose in western North America. USDA Forest Service Gen. Tech. Rep. INT-152. Intermountain Forest and Range Experiment Station, Ogden, Utah.

McArthur, E.D., and B.L. Welch (complers). 1986. Proceedingssymposium on the biology of Artemisia and Chrysothamnus. USDA Forest Service Gen. Tech. Rep. INT-200. Intermountain Research Station, Ogden, Utah.

National Oceanic and Atmospheric Administration. 1982-1986. Climatological data, Utah. Vol. 84-88. National Climatic Data Center, Asheville, N.C.

Personius, T.L., C.L. Wambolt, J.R. Stephens, and R.G. Kelsey. 1987. Crude terpenoid influence on mule deer preference of sagebrush. J. Range Manage. 40:84-88.

Pickford, G.D. 1932. The influence of continued heavy grazing and of promiscuous burning on spring-fall ranges in Utah. Ecology 13:159-171.

Piemeisel, R.L. 1951. Causes affecting change and rate of change in a vegetation of annuals in Idaho. Ecology 32:53-72.

Platou, K.A., and P.T. Tueller. 1985. Evolutionary implications for grazing management systems. Rangelands 7:57-61.
Pollard, J.H. 1977. A handbook of numerical and statistical techniques. Cambridge Univ. Press, London.

Smith, A.D. 1949. Effects of mule deer and livestock upon foothill range in northern Utah. J. Wildl, Manage. 13:421-423.

Smith, A.D. 1964. Defecation rates of mule deer. J. Wildl. Manage. 28:435-444.

Stevens, J.C., R.C. Brough, R.D. Grifin, and E.A. Richardson. 1983. Utah weather guide. Society for Applied Climatology, West Jordan, Utah.

Welch, B.L., and E.D. McArthur. 1986. Wintering mule deer preference for 21 accessions of big sagebrush. Great Basin Natur. 46:281-286.

Welch, B.L., E.D. McArthur, and R.L. Rodriguez. 1987. Variation in utilization of big sagebrush accessions by wintering sheep. J. Range Manage. 40:113-115.

Welah, S.L., N.D. Atwood, S. Goodrich, and L. Higgins (eds.). 1987. A Utah flora. Great Basin Natur. Mem. 9:1-894.

Welch, S.L., N.D. Atwood, S. Goodrich, K.H. Thome, and B. Albee. 1981. Preliminary index of Utah vascular plant names. Great Basin Natur. 41:1-108.

Youns, J.A., R.E. Eekert, Jr., and R.A. Evans. 1979. Historical perspectives regarding the sagebrush ecosystem. p. 1-13. In: The sagebrush ecosystem: a symposium. College of Natural Resources, Utah State Univ., Logan. 